\title{
Produksi Karbon Aktif dari Cangkang Sawit dan Aplikasinya Pada Penyerapan Zat Besi, Mangan Dan ph Air Sumur
}

\author{
Vera Viena $^{1}$, Bahagia $^{2}$, Zairi Afrizal $^{3}$ \\ ${ }^{1,2,3}$ Program Studi Teknik Lingkungan Fakultas Teknik Universitas Serambi Mekkah \\ Jl. Tgk Imum LuengBata Batoh, Banda Aceh, Indonesia \\ *Koresponden email: veraviena@serambimekkah.ac.id
}

Diterima: 18 Desember 2019

Disetujui: 20 Desember 2019

\begin{abstract}
Most of the solid waste from Palm oil Industry in Indonesia has not been exploited optimally to become valuable product. This research aims to produce activated carbon from palm oil shell waste and applied it for the adsorption of $\mathrm{Fe}, \mathrm{Mn}$ and $\mathrm{pH}$ of shallow well. Production of Palm shell activated carbon (PSAC) were done under following steps; e.i palm shell preparation, oven dried, carbonization at $400{ }^{\circ} \mathrm{C}$, dan then activated at $600{ }^{\circ} \mathrm{C}$. PSAC Characterization conducted based on Indonesion Standard of SNI No.063730-95, which consist of water content, ash content, fly ash content and fixed carbon, while surface of PSAC analized using FTIR method. Shallow well sampling were taken from 2 wells from Drien Tujoh Village, Nagan Raya District. PSAC contacted time varied from 30-120 minute. The highest PSAC adsorption efficiency were obtained both at 120 minute contacted time, which range from 10,41 $58,34 \%$ for $\mathrm{Fe}(\mathrm{II}) ; 9,51-48,90 \%$ for $\mathrm{Mn}$ (II) and $\mathrm{pH}$ raised from 5,8 to 7,6. In conclusion, the PSAC product has been able to remove $\mathrm{Fe}, \mathrm{Mn}$ and $\mathrm{pH}$ content in accordance with water quality standard published by Indonesian Government, and it could be marketed for increasing the people's income.

Keywords: Palm Shell Activated Carbon (PSAC), Adsorption of Fe and Mn, Shallow well, palm, sludge

Abstrak

Limbah padat industri pengolahan kelapa sawit Indonesia belum sepenuhnya dimanfaatkan optimal menjadi produk bernilai jual. Penelitian ini bertujuan untuk memproduksi karbon aktif dari limbah cangkang kelapa sawit dan diaplikasikan pada penyerapan kadar Fe, Mn dan $\mathrm{pH}$ air sumur. Karbon aktif cangkang sawit (KACS) diproduksi melalui tahapan yaitu preparasi, pengeringan dengan oven, karbonisasi pada suhu $400{ }^{\circ} \mathrm{C}$, dan aktivasi pada suhu $600{ }^{\circ} \mathrm{C}$. Uji karakteristik KACS dilakukan berdasarkan SNI No.06-3730-95 meliputi kadar air, kadar abu, kadar zat terbang dan karbon tetap, sedangkan uji permukaan KACS menggunakan metode FTIR. Variabel waktu kontak KACS berkisar dari 30-120 menit. Pengambilan sampel air sumur diambil dari 2 titik di Desa DrienTujoh Kab. Nagan Raya. Efisiensi penyerapan KACS tertinggi pada kedu atitik air sumur diperoleh pada waktu kontak 120 menit, dengan persentase efisiensi berturut-turut; untuk Fe berkisar antara 10,41 - 58,34\%, Mn 9,51 48,90\% dan $\mathrm{pH}$ naik dari 5,8 menjadi 7,6. Dapat disimpulkan bahwa produk KACS mampu menurunkan kadar Fe, Mn dan pH sesuai baku mutu air yang ditetapkan oleh Pemerintah dan produk KACS dapat dijual untuk peningkatan ekonomi masyarakat.
\end{abstract}

Kata Kunci: Karbon aktif Cangkang Sawit (KACS), Penyerapan Fe dan Mn, Air Sumur, sawit,sludge

\section{Pendahuluan}

Produksi limbah padat dan limbah cair dari pabrik pengolahan kelapa sawit Indonesia cenderung makin meningkat, berbanding lurus dengan peningkatan produksi tandan buah segar (TBS) dan luas areal perkebunan kelapa sawit. Berdasarkan neraca massa kelapa sawit, maka diperkirakan produksi limbah padat kelapa sawit pada tahun 2017 adalah produksi mesocarp fibre sebanyak 20 juta ton, cangkang sebanyak 9 juta ton, tandan kosong sebanyak 31 juta ton. Saat ini biomassa kelapa sawit seperti pelepah, batang, cangkang, serat mesocarp, tandan kosong kelapa sawit dan Palm Kernel Mill (PKM), sudah dimanfaatkan, namun pemanfaatannya belum optimal [1].

Sampai tahun 2018, Produksi sawit Aceh terdiri dari 3 sumber yaitu: (1) Perkebunan rakyat (smallholders) memiliki luas lahan 155.581 hektar dan produksi 455.184 ton, (2) Perkebunan negara memiliki luas sebesar 25.499 hektar dan produksi 72.594 ton, dan (3) Perkebunan swasta memiliki luas lahan 140.822 hektar dan jumlah produksi 549.321 ton. Secara keseluruhan, jumlah total luas lahan sawit 
di Aceh adalah 321.903 hektar dan 1.077.099 ton produksi, dengan luas area perkebunan terbesar terletak di Kabupaten Nagan Raya [2].

Studi oleh [3], komposisi utama cangkang kelapa sawit adalah hemiselulosa, selulosa dan lignin. Proses pirolisis dari cangkang kelapa sawit dapat menghasilkan lebih dari 400 senyawa aktif yang dapat digunakan sebagai bahan industri. Penelitian [4] menyebutkan bahwa cangkang kelapa sawit dapat dimanfaatkan sebagai karbon/arang aktif, pembuatan pupuk cair kalium sulfat, pengawet alami tahu, bahan bakar (biomassa), dan briket. Penambahan arang aktif cangkang kelapa sawit (Elaeis guineensis) dalam proses filtrasi cukup efektif dalam memperbaiki kualitas fisik air sumur.

Kualitas air sumur di wilayah Nagan Raya sangat dipengaruhi oleh kondisi geografis yang banyak dialiri sungai dan berdekatan dengan perkebunan sawit. Hal ini dibuktikan dengan data dari Kelompok Kerja Sanitasi Nagan Raya melalui survey [5] Environmental Health Risk Assessment (EHRA) (2013), bahwa masyarakat di Kabupaten Nagan Raya paling banyak mengkonsumsi air sumur gali terlindung untuk diminum dan menggunakan air sungai untuk memasak. Penggunaan air sungai mencapai 62,5\% dan air sumur gali terlindungi untuk minum mencapai $40,8 \%$, sementara penggunaan sumber air lainnya baik untuk keperluan minum maupun masak rata-rata masih dibawah angka 20\%. Dari 13 desa yang di survey kondisi sumber air terlindungi, hanya 3 desa yang aman dari resiko. Sedangkan 10 desa lainnya beresiko tinggi kesehatan lingkungannya.

Permasalahan yang sering dijumpai dengan wilayah-wilayah belum mendapat pelayanan air bersih (PAM) adalah sebagian masyarakat menggunakan sumur gali dengan kualitas air tanah yang kurang memenuhi syarat sebagai air bersih dan air minum yang sehat [6]. Untuk itu perlu diterapkan teknik pengolahan air untuk meningkatkan kualitas sumber air bersih di Kabupaten Nagan Raya dan daerah lainnya di Aceh dengan menggunakan limbah sisa perkebunan sawit yang ada disekitar desa. Riset [7] menyebutkan bahwa munculnya ion Mn dalam air tanah biasanya diikuti dengan hadirnya ion besi yang terlepas dari tanah dan batuan. Ion-ion logam Mn dan Fe dalam air dapat dideteksi secara laboratorium atau dapat ditandai secara organoleptik. Teknik penyisihan logam Mn dalam limbah cair dan air bersih telah dilaporkan keberhasilannya oleh [8], yaitu proses oksidasi-filtrasi sebesar 95\% Mn, presipitasi kimia sebesar 99.5\% Mn, dan adsorpsi sebesar 99,42\% Mn. Penelitian oleh [9] telah menguji penambahan arang aktif cangkang kelapa sawit dalam proses filtrasi terhadap karakter fisik (kekeruhan, $\mathrm{Ph}$, bau dan rasa) air sumur.

Sebagai akibat dari belum optimalnya pemanfaatan limbah padat kelapa sawit menjadi produk bernilai jual ekonomis, maka peneliti bermaksud menguji karbon aktif dari limbah cangkang kelapa sawit (KACS) untuk dapat diaplikasikan pada penjernihan air khususnya pada penyerapan kadar $\mathrm{Fe}$, Mn dan $\mathrm{pH}$ air sumur warga di Nagan Raya, Aceh. Penelitian sebelumnya oleh [10] telah menguji penggunaan suhu $600{ }^{\circ} \mathrm{C}$ untuk karbonisasi arang dari cangkang sawit. Namun peneliti tersebut menggunakan suhu aktivasi $900{ }^{\circ} \mathrm{C}$ dan telah menunjukkan hasil terbaik dengan kadar air dan kadar abu berada dibawah standar SNI (1995) [11]. Pada penelitian ini digunakan metode pembuatan karbon aktif melalui proses karbonisasi pada suhu $400{ }^{\circ} \mathrm{C}$ selama 1,5 jam dan dilanjutkan dengan proses aktivasi pada suhu $600{ }^{\circ} \mathrm{C}$ selama 30 menit.

Diharapkan penelitian ini dapat menghasilkan produk karbon aktif cangkang sawit (KACS) yang mampu meningkatkan kualitas air sumur warga di Nagan Raya yang terkontaminasi Fe dan Mn. Penjernihan air sumur masyarakat di Aceh yang umumnya menggunakan arang kayu dan arang tempurung kelapa, dapat beralih ke karbon aktif dari limbah cangkang kelapa sawit yang masih belum banyak dimanfaatkan, sehingga produk KACS ini dapat menyumbang nilai ekonomis jika dijual ke masyarakat.

\section{Metodologi Penelitian}

\section{Pembuatan produk karbon aktif dari cangkang sawit (KACS)}

Limbah cangkang kelapa sawit dikumpulkan dari Pabrik kelapa sawit di Nagan Raya sebanyak 5 $\mathrm{kg}$, dipilah-pilah, dicuci bersih, dikering anginkan $1 \times 24$ jam dan di oven pada suhu $105^{\circ} \mathrm{C}$ untuk mengurangi kandungan air bahan cangkang sawit. Cangkang kering selanjutnya di karbonisasi pada suhu $400{ }^{\circ} \mathrm{C}$ selama 1,5 jam menjadi arang dan dilanjutkan dengan aktivasi fisika secara termal pada furnace tanpa aliran oksigen dengan suhu $600{ }^{\circ} \mathrm{C}$ selama 30 menit. Produk karbon aktif cangkang sawit (KACS) ditumbuk dan diayak untuk memperoleh ukuran seragam 50 mesh. Produk karbon aktif ini selanjutnya digunakan dalam keseluruhan uji penyerapan kadar $\mathrm{Fe}, \mathrm{Mn}$ dan $\mathrm{pH}$ air sumur warga.

\section{Karakterisasi KACS}

Uji karakteristik karbon aktif yang dilakukan meliputi uji kadar air, kadar abu, kadar zat terbang dan kadar karbon tetap berdasarkan SNI No.06-3730-95. Menurut [12] persamaan yang digunakan untuk 
menghitung secara proximate kadar air, kadar abu, kadar zat terbang dan kadar karbon tetap diurutkan sebagai berikut:

\section{Uji Kadar Air}

Timbang 1 gram sampel kedalam kertas saring yang telah diketahui beratnya. Panaskan dalam oven pada suhu $110^{\circ} \mathrm{C}$ selama 1 jam. Dinginkan dalam eksikator dan ditimbang.

$$
\mathrm{M}=\frac{M_{2}-M_{3}}{M_{2}-M_{1}} \times 100
$$

Dimana: $\mathrm{M}$ (kandungan air yang dianalisa (\%), $\mathrm{M}_{1}$ (berat kertas saring), $\mathrm{M}$ (berat kertas saring +sampel sebelum dioven) dan $\mathrm{M}_{3}$ (berat kertas saring + sampel setelah dioven).

\section{Uji Kadar Abu}

Timbang 1 gram sampel dalam porselin yang telah diketahui beratnya. Diabukan dalam furnace pada suhu $815^{\circ} \mathrm{C}$ selama 1 jam. Kemudian metal plate di dinginkan dalam eksikator lalu ditimbang.

$$
\text { Kadar Abu }=\frac{X_{2}-X_{3}}{X_{2}-X_{1}} \times 100
$$

Dimana: $X_{1}$ (berat porselin), $X_{2}$ (berat porselin+sampel sebelum dioven) dan $X_{3}$ (berat porselin+ sampel setelah dioven).

\section{Uji Zat terbang (ZT)}

Timbang porselin, masukkan 1 gram sampel dan timbang kembali.Masukkan porselinyang berisi sampel ke dalam furnace selama 7 menit dengan suhu $900^{\circ} \mathrm{C}$. Keluarkan porselindari furnace dan ditimbang.

$$
\mathrm{VM}=\frac{M_{2}-M_{3}}{M_{2}-M_{1}} \times 100-\mathrm{M}
$$

Dimana: VM (kandungan zat terbang (vollatile matter dalam \%), $\mathrm{M}_{1}$ (berat porselin), $\mathrm{M}_{2}$ (berat porselin dan contoh sebelum dipanaskan), $\mathrm{M}_{3}$ (berat porselin dan sampel setelah dipanaskan) dan $\mathrm{M}$ (kandungan air setelah dianalisa).

\section{Uji Karbon Tetap}

Kadar Karbon tetap dapat diperoleh dengan rumus:

$$
\text { Karbon Tetap }=100-(\text { kadar air }+ \text { kadar abu }+ \text { ZT })(\text { dalam \% })
$$

\section{Uji permukaan KACS menggunakan FTIR}

Uji karakteristik permukaan karbon aktif dilakukan dengan menggunakan metode Fourier Transform Infra Red (FTIR) sebelum dan sesudah aktivasi fisika. Uji ini berguna untuk mengetahui gugus fungsi pori-pori permukaan yang dimiliki oleh karbon aktif cangkang sawit teraktivasi secara termal. Uji FTIR dilakukan pada panjang gelombang $4000-400 \mathrm{~cm}^{-1}$. Hasil uji FTIR berupa grafik dengan puncak-puncak transmisi panjang gelombang yang dapat mewakili gugus fungsi spesifik dari permukaan karbon aktif yang dapat menyerap logam berat Fe dan Mn pada air sumur.

\section{Pengambilan sampel air sumur}

Pengambilan sampel air sumur dilakukan di Desa Drien Tujoh Kecamatan Tripa Makmur Kabupaten Nagan Raya Aceh. Lokasi sampel berdekatan dengan Pabrik Kelapa Sawit Fajar Baizury Brother (PKSFBB) dan sungai yang mengaliri desa dan sekitarnya. Sampel air diambil dari 2 titik sumur yang berdekatan dengan PKSFBB dan yang berdekatan dengan rumah warga. Dua sampel air sumur diambil dengan menggunakan water sampler dan dimasukkan ke dalam wadah jerigen plastik volume 5 liter, untuk kemudian disimpan dalam cold box. Sampel air sumur digunakan untuk uji kandungan $\mathrm{Fe}, \mathrm{Mn}$ dan $\mathrm{pH}$ (awal) sebelum perlakuan, dan setelah diberi perlakuan KACS. Lokasi pengambilan sampel air sumur dapat dilihat pada Gambar 1. 


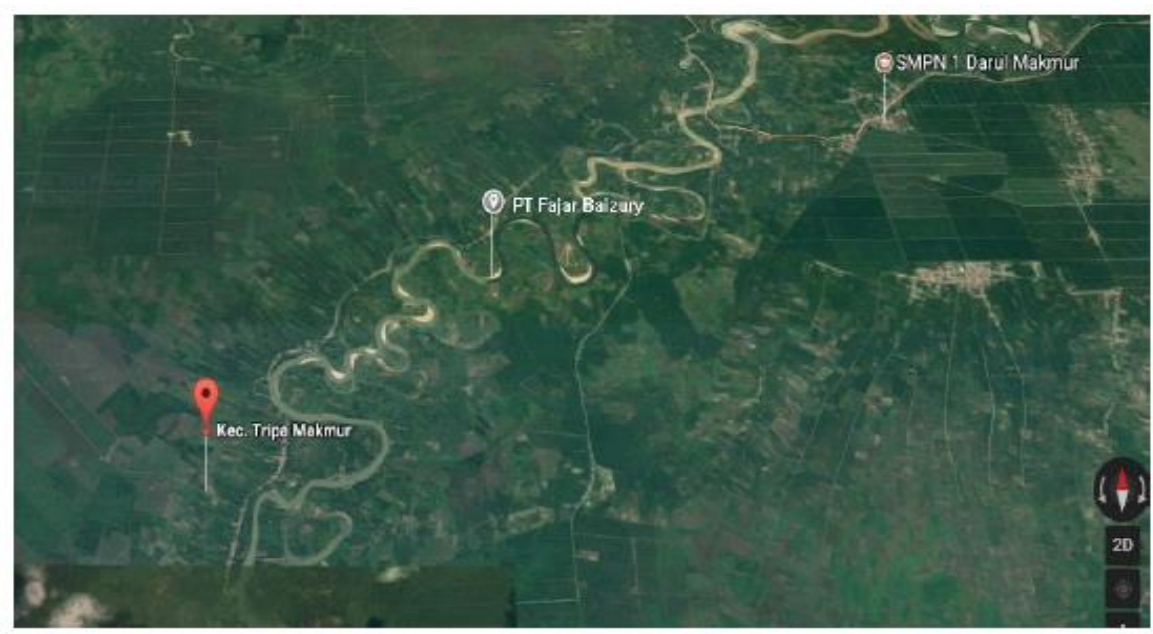

Gambar 1. Lokasi pengambilan sampel air sumur di Desa Drien Tujoh Kabupaten Nagan Raya

\section{Uji pengaruh waktu kontak KACS terhadap adsorpsi Fe dan Mn pada air sumur}

Pada tahap ini dilakukan uji pengaruh waktu kontak KACS dengan karakteristik terbaik pada variasi 30, 60, 90 dan 120 menit terhadap air sumur warga di Nagan Raya. Dua sumur warga yang dipilih adalah yang masih aktif dan terletak dekat dengan sumber Pabrik kelapa sawit. Penentuan waktu kontak dilakukan dengan mengambil larutan air sumur sebanyak $100 \mathrm{ml}$ dan dimasukkan ke dalam erlenmeyer $250 \mathrm{ml}$ yang berbeda, kemudian dikontakkan dengan adsorben KACS dengan dosis $10 \mathrm{gr} / \mathrm{L}$. Larutan selanjutnya diaduk dengan pengaduk magnetik pada kecepatan $200 \mathrm{rpm}$ selama 30, 60, 90, dan 120 menit. Masing-masing air sumur selanjutnya disaring dan dianalisis konsentrasi Fe, Mn dan $\mathrm{pH}$ akhir. Hasil analisis konsentrasi akhir Fe, Mn digunakan untuk menghitung presentase efisiensi penyerapan.

Persamaan yang digunakan untuk menghitung persentase efisiensi penyerapan logam berat Fe dan Mn, adalah sebagai berikut:

$$
\begin{aligned}
& \text { Efisiensi }(\%)=(\text { Fe awal }- \text { Fe akhir }) /(\text { Fe awal }) * 100 \% \\
& \text { Efisiensi }(\%)=(\text { Mn awal }- \text { Mn akhir }) /(\text { Mn awal })^{*} 100 \%
\end{aligned}
$$

\section{Hasil dan Pembahasan}

\section{Proses pembuatan produk KACS}

Pembuatan karbon aktif dari limbah cangkang kelapa sawit diawali dengan pemilahan dan pencucian limbah cangkang yang akan diolah menjadi karbon. Hal ini dilakukan untuk membersihkan debu dan kotoran yang melekat pada sampel cangkang sawit sebelum diberi perlakuan karbonisasi pada keadaan tanpa oksigen. Suhu karbonisasi awal pada $400{ }^{\circ} \mathrm{C}$ umumnya dipilih karena pada biomassa keras yang mengandung bahan selulosa dan hemi- selulosa seperti cangkang sawit masih mampu menyisakan kandungan karbon dan telah terbentuk senyawa karbon untuk penyerapan zat-zat pencemar di lingkungan.

Aktivasi secara thermal pada suhu $600{ }^{\circ} \mathrm{C}$ telah terbukti mampu menghasilkan karakteristik karbon aktif yang sesuai membuka pori-pori karbon aktif sehingga mampu meningkatkan kemampuan penyerapan zat pengotor dalam air. Pemanfaatan limbah cangkang sawit sebagai karbon aktif untuk berbagai kebutuhan haruslah semakin digerakkan untuk menumbuhkan ekonomi warga dan sekaligus dapat digunakan untuk menjernihkan air minum sehari-hari.

Beberapa peneliti memiliki pendapat berbeda mengenai proses terbaik untuk produksi karbon aktif dari cangkang sawit. Penelitian oleh [13], menujukkan bahwa proses karbonisasi cangkang kelapa sawit yang terbaik diperoleh pada suhu $500^{\circ} \mathrm{C}$ dan waktu 3 jam. Aktivasi dengan $\mathrm{NaOH}$ selama 4 jam menunjukkan hasil terbaik dengan kadar air arang aktif 3,6 \% dan daya serap Iodine $851,8797 \mathrm{mg} / \mathrm{g}$. Sedangkan penelitian oleh [14] menggunakan suhu karbonisasi pada vacuum furnace dengan variasi $500^{\circ}$ $\mathrm{C}$ dan $1000^{\circ} \mathrm{C}$ selama 40 menit, menghasilkan unsur karbon cukup tinggi yaitu sekitar $48 \%$ untuk temperatur $500 \mathrm{oC}$ dan $50 \%$ pada $1000^{\circ} \mathrm{C}$. Gambar 2 memperlihatkan kondisi fisik cangkang sawit sebelum dan sesudah dibuat menjadi karbon aktif. 


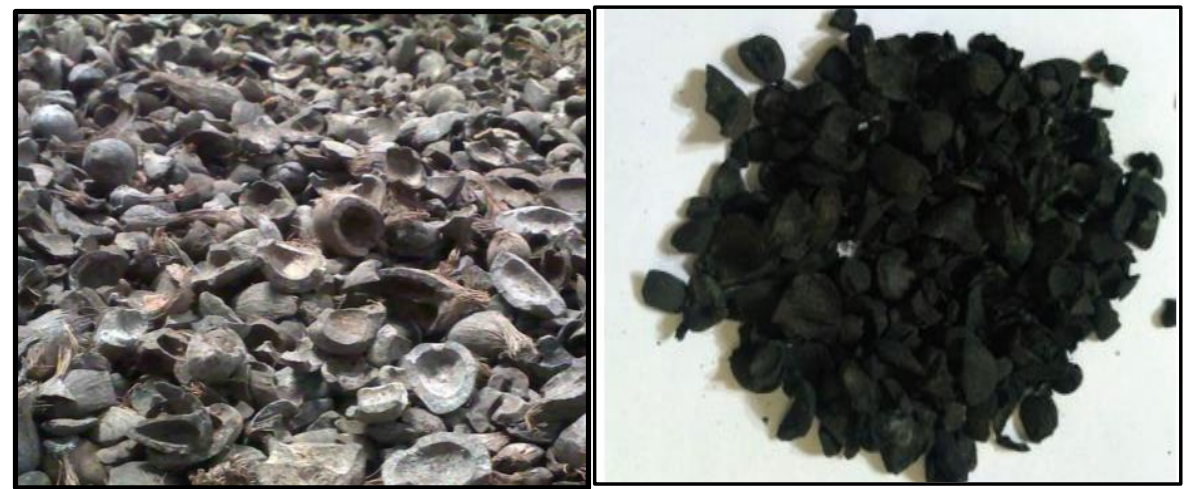

Gambar 2. Cangkang sawit sebelum dan setelah dikarbonisasi menjadi karbon aktif

Menurut [15] mutu arang aktif ditentukan oleh sifat-sifatnya, yaitu luas permukaan, distribusi pori, dan daya adsorpsi. Sifat-sifat ini juga dimiliki oleh arang, tetapi nilainya lebih kecil. Luas permukaan merupakan parameter yang erat hubungannya dengan kemampuan adsorpsi suatu adsorben. Berdasarkan SNI Nomor 06-3730- 1995 (Tabel 1), untuk dapat digunakan secara luas, arang aktif harus memenuhi standar yang telah ditetapkan Standar Nasional Indonesia.

Tabel 1. Karakteristik KACS berdasarkan uji proksimat

\begin{tabular}{cccc}
\hline Karakteristik KACS & $\mathrm{T}=400{ }^{0} \mathrm{C}$ & $\mathrm{T}=600{ }^{\circ} \mathrm{C}$ & $\begin{array}{c}\text { Baku Mutu } \\
\text { SNI No.06-3730- } \\
1995\end{array}$ \\
\hline Kadar air & 16 & 14 & 15 \\
Kadar Abu & 13 & 10 & 10 \\
Zat Terbang & 18 & 16 & 25 \\
Karbon Tetap & 53 & 60 & 75 \\
\hline
\end{tabular}

\section{Hasil karakterisasi KACS}

Karakterisasi KACS pada penelitian ini meliputi kadar air, kadar abu, kadar zat terbang dan karbon tetap. Penentuan uji karakteritik KACS berpanduan pada SNI 06-3730 - 1995. Pada Tabel 1. ditabulasikan hasil karakterisasi KACS berdasarkan uji proksimat.

Kadar air untuk karbon aktif sebelum teraktivasi (suhu $400{ }^{\circ} \mathrm{C}$ ) diperoleh $16 \%$, sedangkan setelah teraktivasi pada suhu $600{ }^{\circ} \mathrm{C}$ berada dibawah standar yaitu $14 \%$. Kadar air yang masih tinggi ini dipengaruhi oleh penggunaan waktu aktivasi 30 menit, sehingga masih tersisa kandungan air dalam bahan cangkang yang belum teruapkan dengan sempurna saat proses aktivasi selama 30 menit tersebut. Selain itu proses pengeringan awal yang terbuka pada saat preparasi sampel cangkang sawit sebelum dikarbonisasi juga berpengaruh kepada tingginya kandungan air bahan, karena karakteristik cangkang sawit yang berbahan keras cenderung menyimpan air dalam bahan.

Abu merupakan sisa pembakaran yang merupakan komponen anorganik yang tertinggal setelah bahan dipanaskan pada suhu $400-600{ }^{\circ} \mathrm{C}$ dan terdiri dari kalium, natrium, magnesium, kalsium, serta komponen lain dalam jumlah kecil. Kadar abu sebelum aktivasi bernilai $13 \%$ dan setelah aktivasi menurun menjadi $10 \%$. Kadar abu telah memenuhi standar maksimum SNI 10\%. Kandungan air yang masih tinggi dapat menyisakan abu berwarna kehitaman yang menyebabkan zat terbang yang dihasilkan juga semakin tinggi. Semakin besar kandungan abu maka akan berefek pada kemampuan penyerapan besi dan mangan pada sampel air sumur yang diteliti.

Sebagai pembanding, penelitian oleh Harahap, dkk (2014) menunjukkan hasil karakteristik pada cangkang kelapa sawit dengan uji proksimat, yaitu kadar air yang terbaik terdapat pada suhu $600^{\circ} \mathrm{C}$ yaitu sebesar 4,5\% yang memenuhi Standar Industri Indonesia (SII), nilai kadar abu yang yang didapatkan pada suhu $600^{\circ} \mathrm{C}$ pada waktu 60 menit yaitu sebesar 9,7\%, nilai bilangan iodine yang didapatkan pada penelitian tersebut yang tertinggi yaitu $353 \mathrm{mg} / \mathrm{gr}$ yang diperoleh pada suhu aktivasi $900{ }^{\circ} \mathrm{C}$ dengan waktu 60 menit dan rendemen $48 \%$.

\section{Hasil uji permukaan KACS dengan FTIR}

Karakterisasi sampel dengan menggunakan metode spektrofotometri infra merah bertujuan untuk menentukan gugus fungsi yang ada dalam sampel. Karakterisasi dilakukan terhadap karbon sebelum aktivasi dan arang setelah aktivasi. Hasil uji FTIR menunjukkan empat puncak utama dengan persen pita 
serapan antara $81.647-94.110 \%$ dengan bilangan gelombang berkisar antara $3650-440 \mathrm{~cm}^{-1}$. Puncakpuncak serapan tertinggi tersebut ditabulasikan pada Tabel 2.

Tabel 2. Hasil analisa FTIR KACS dengan puncak-puncak utama

\begin{tabular}{cccc}
\hline No. & Puncak Panjang gelombang $\left(\mathrm{cm}^{-1}\right)$ & \% Transmisi & Nama gugus fungsi \\
\hline 1 & 690.240 & 84.543 & C-H kuat \\
2 & 1022.751 & 83.955 & C-O \\
3 & 1652.934 & 94.110 & C=C \\
4 & 3614.767 & 81.647 & O-H sedang \\
\hline
\end{tabular}

Perbedaan suhu pada pembakaran arang $\left(400\right.$ dan $\left.600{ }^{\circ} \mathrm{C}\right)$ tidak memberikan perbedaan signifikan pada gugus fungsi permukaan karbon aktif KACS yang dihasilkan.

\section{Analisa kualitas air sumur}

Pengambilan air sumur untuk analisa kandungan Fe dan Mn dilakukan pada 2 lokasi sumur warga di Desa Drien Tujoh Kab.Nagan Raya. Air sumur warga yang dipilih adalah air sumur yang masih aktif dipakai warga dengan penampakan fisik sedikit berbau seperti besi dan berubah warna menjadi keruh dan kehitaman jika disimpan lama. Hasil analisa awal kualitas air sumur di Desa Drien Tujoh ditabulasikan pada Tabel 3.

Tabel 3. Kualitas air sumur Desa Drien Tujoh, Kab. Nagan Raya

\begin{tabular}{llccccc}
\hline & & & & \multirow{2}{c}{ Baku Mutu } & \multicolumn{2}{c}{ Hasil Uji } \\
\cline { 5 - 7 } No. & Parameter Uji & Satuan & Metode Uji & $\begin{array}{c}\text { (Permenkes } \\
\text { No.492/2010) }\end{array}$ & $\begin{array}{c}\text { Air Sumur } \\
1 \text { (AS 1) }\end{array}$ & $\begin{array}{c}\text { Air Sumur } \\
2(\text { AS 2) }\end{array}$ \\
\hline 1. & Besi (Fe) & $\mathrm{mg} / \mathrm{L}$ & SNI 01-3554-2016 & Maks. 0.3 & 0,7185 & 0,7652 \\
2. & Mangan $(\mathrm{Mn})$ & $\mathrm{mg} / \mathrm{L}$ & SNI 01-3554-2016 & Maks. 0.4 & 0,7863 & 0,8349 \\
3. & $\mathrm{pH}$ & - & $6-9$ & 5,8 & 5,8 & 5,4 \\
\hline
\end{tabular}

Kandungan besi (Fe) awal sebelum perlakuan pada Air Sumur 1 (AS1) sebesar $0.7185 \mathrm{mg} / \mathrm{L}$ dan Air Sumur 2 (AS2) sebesar 0.7652. Kandungan Fe pada kedua air sumur warga ini terbukti melebihi standar yang ditetapkan Permenkes No.492/2010 [16] yaitu maksimal 0.3 mg/L. Sedangkan kandungan Mangan (Mn) pada AS1 dan AS2 berturut-turut 0.7863 dan $0.8349 \mathrm{mg} / \mathrm{L}$, yang melebihi standar yang ditetapkan yaitu $0.4 \mathrm{mg} / \mathrm{L}$. Hal ini menjadi dasar bahwa air sumur warga telah tercemar Fe dan Mn dan perlu dilakukan pengolahan terlebih dahulu sebelum dipakai sebagai sumber air bersih.

\section{Pengaruh waktu kontak terhadap penyerapan Fe, Mn dan pH air sumur}

Salah satu upaya untuk membersihkan air sumur yang keruh adalah dengan cara penyaringan dengan membuat saringan pasir lambat yang diisi dengan kerikil, ijuk dan pasir. Selanjutnya dengan penambahan arang aktif memberikan hasil yang optimal dalam proses penyaringan karena fungsi dari arang aktif sebagai penyerap [17]. Penyerapan kandungan Fe dan Mn pada air sumur warga Desa Drien Tujoh dilakukan dengan menambahkan karbon aktif cangkang sawit (KACS) langsung kedalam sampel air sumur dengan variasi perlakuan waktu kontak bervariasi dari 30, 60, 90 dan 120 menit.

Variasi waktu kontak ini dimaksudkan untuk mengetahui lama waktu pengontakan optimum untuk penyerapan Fe dan Mn. Pada Tabel 4 ditabulasikan hasil analisa kualitas air sumur yang diberikan variasi waktu kontak dengan KACS.

Tabel 4. Kualitas air sumur Desa Drien Tujoh setelah perlakuan KACS

\begin{tabular}{cccccc}
\hline \multirow{2}{*}{ No. } & \multirow{2}{*}{ Sampel } & \multirow{2}{*}{$\begin{array}{c}\text { Waktu Kontak } \\
\text { (menit) }\end{array}$} & $\mathrm{pH}$ & Besi (mg/L) & Mangan (mg/L) \\
\cline { 4 - 6 } 1 & \multirow{2}{*}{ Air sumur 1 (AS 1) } & 30 & 6,2 & 0,6437 & 0,7115 \\
& & 60 & 6,7 & 0,5489 & 0,6167 \\
& & 90 & 7,1 & 0,4341 & 0,5019 \\
& & 120 & 7,6 & 0,2993 & 0,3671 \\
\hline \multirow{2}{*}{2} & Air sumur 2 (AS 2) & 30 & 5,7 & 0,6864 & 0,7561 \\
& & 60 & 6,4 & 0,5876 & 0,6573 \\
& & 90 & 6,9 & 0,4688 & 0,5385 \\
& & 120 & 7,3 & 0,3300 & 0,3997 \\
\hline
\end{tabular}


Dari data uji penurunan Fe dan Mn pada Tabel 4. menunjukkan bahwa waktu kontak 120 menit telah memberikan nilai penyerapan maksimum baik untuk logam $\mathrm{Fe}$ maupun $\mathrm{Mn}$ dan telah mampu menurunkan kandungan Fe dan Mn dibawah standar. Terbukti dari nilai awal Fe Air Sumur 1 (AS1) sebesar 0,7185 mg/L dapat menurun menjadi 0,2993 (efisiensi serapan 58,34 \%) sedangkan pada Air Sumur 2 (AS2) kandungan Fe sebesar 0,7652 mg/L dapat turun menjadi 0,3300 mg/L (efisiensi serapan $56,87 \%$ ). Untuk penurunan kandungan Mn dapat dilihat bahwa waktu kontak 120 menit juga telah mampu menurunkan $\mathrm{Mn}$ dari nilai awal $0,7863 \mathrm{mg} / \mathrm{L}$ menjadi $0,3671 \mathrm{mg} / \mathrm{L}$ (efisiensi serapan 48,90\%) pada AS1 dan pada AS2 turun dari $0,8349 \mathrm{mg} / \mathrm{L}$ menjadi $0,3997 \mathrm{mg} / \mathrm{L}$ (efisiensi serapan 52,12\%). Hasil serapan Mn pada sumur AS1 dan AS2 keduanya telah sesuai dengan standar yang ditetapkan pemerintah, yaitu dibawah $0,4 \mathrm{mg} / \mathrm{L}$. Walaupun persentase penyerapan belum mencapai $100 \%$, namun tingkat penyerapan oleh karbon aktif cangkang sawit telah memenuhi standar.

Jadi dapat dinyatakan bahwa penggunaan KACS sangat berpotensi untuk diaplikasikan dalam penyerapan logam berat $\mathrm{Fe}$ dan $\mathrm{Mn}$, juga sekaligus dapat menurunkan nilai $\mathrm{pH}$ dari asam menjadi netral. Kualitas air sumur yang dihasilkan tidak lagi berbau dan tidak lagi membentuk endapan berwarna hitam. air menjadi lebih jernih dan kualitas air telah sesuai dengan Permenkes No.492/2010. Pada Gambar 3 menampilkan secara keseluruhan persentase penyerapan Fe dan Mn pada waktu kontak berbeda, baik pada air sumur 1 dan air sumur 2 .

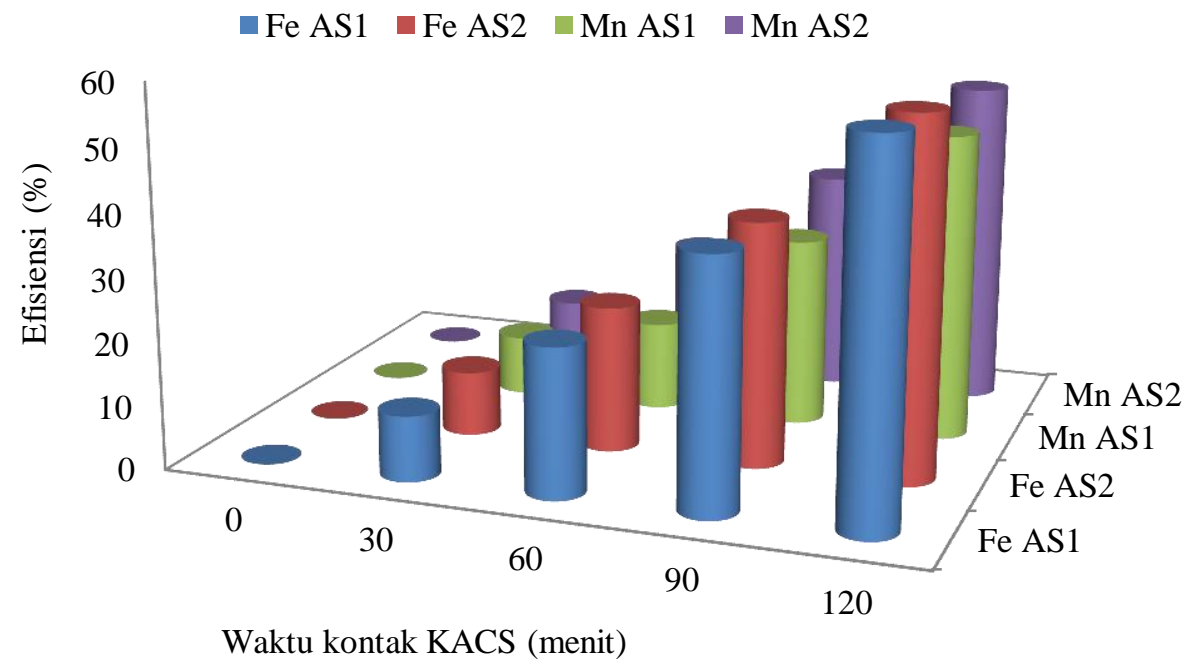

Gambar 3. Persentase efisiensi penyerapan Fe dan Mn pada waktu kontak berbeda

Disarankan bahwa perlu dilakukan peningkatan suhu karbonisasi cangkang sawit sampai $800{ }^{\circ} \mathrm{C}$, karena berdasarkan Penelitian yang dilakukan [18] bahwa penggunaan karbon aktif dari suhu aktivasi 800 ${ }^{0} \mathrm{C}$ menghasilkan air yang jernih, tidak berbau dan memenuhi $\mathrm{pH}$ standar air (7,0-7,5). Produk KACS yang telah dihasilkan sangat berpotensi sebagai zat karbon penyerap kontaminan besi dan mangan pada air sumur warga sehingga layak untuk diminum dan sekaligus dapat dijual untuk menambah nilai ekonomis warga.

\section{Kesimpulan}

Berdasarkan penelitian yang telah dilakukan dapat diambil kesimpulan yaitu:

1. Produk KACS memiliki karakteristik kadar air sebesar 14-16 \%, kadar abu 10-13\%, kadar zat menguap 16-18\%, dan karbon tetap 53-60.

2. Hasil uji pengaruh waktu kontak KACS terhadap air sumur (AS) 1, menunjukkan efisiensi penyerapan kadar Fe berkisar antara 10,41 - 58,34\%, kadar Mn 9,51 - 48,90\% dan pH mengalami peningkatan dari 5,8 menjadi 7,6. Pada air sumur (AS) 2 penyerapan kadar Fe berkisar antara 10,29 - 56,87\% kadar Mn 9,43 - 52,12\%, dan $\mathrm{pH}$ meningkat dari 5,4 menjadi 7,3.

\section{Ucapan Terima Kasih}

Terima kasih yang tidak terhingga penulis ucapkan kepada Laboran Lab. Teknik Lingkungan USM dalam analisa awal karakteristik air sumur, dan Laboran MIPA Unsyiah dalam analisa FTIR karbon aktif cangkang sawit. 


\section{Daftar Pustaka}

[1] https://www.bpdp.or.id/id/sawit-berkelanjutan/potensi-limbah-kelapa-sawit-indonesia/2017/, diakses tanggal 10 September 2019.

[2] https://www.acehtrend.com/2018/01/16/sawit-aceh-dalam-angka/, diakses tanggal 10 September 2019.

[3] F. Fauziati and H. Haspiadi, “Asap Cair dari Cangkang Sawit sebagai Bahan Baku Industri,” J. Ris. Teknol. Ind., vol. 9, no. 2, pp. 177-186, 2016.

[4] P. N. P. Haryanti A., Norsamsi,Sholiha P.S.F., "Studi Pemanfaatan Limbah Padat Kelapa Sawit," J. Konversi, vol. 3, no. 2, pp. 20-22, 2014.

[5] Environmental Health Risk Assessment - Penilaian Resiko Karena Lingkungan, E h r a. Nagan Raya district: Badan Pusat Statistik (BPS), 2013.

[6] L. Febrina, L. Febrina, and A. Ayuna, "Studi Penurunan Kadar Besi (Fe) Dan Mangan (Mn) Dalam Air Tanah Menggunakan Saringan Keramik," J. Teknol., vol. 7, no. 1, pp. 35-44, 2015.

[7] Suhendrayatna, M. Zaki, A. Delima Habdani Harahap, and F. Verantika, "Adsorption of Manganese (II) Ion in the Water Phase by Citric Acid Activated Carbon of Rice Husk," no. August 2019, pp. 547-554, 2018.

[8] D. S. Patil, S. M. Chavan, and J. U. K. Oubagaranadin, "A review of technologies for manganese removal from wastewaters," Journal of Environmental Chemical Engineering, vol. 4, no. 1. pp. 468-487, 2016.

[9] M. Fadhillah and D. Wahyuni, "Efektivitas Penambahan Karbon Aktif Cangkang Kelapa Sawit (Elaeis Guineensis) dalam Proses Filtrasi Air Sumur," J. Kesehat. Komunitas, vol. 3, no. 2, pp. 93-98, 2016.

[10] H. H. Harahap, U. Malik, R. Dewi, F. Matematika, P. Alam, U. Riau, and K. Bina, "Pembuatan Karbon Aktif dari Cangkang Kelapa Sawit Dengan Menggunakan H2O Sebagai Aktivator Untuk Menganalisis Proksimat, Bilangan Iodine dan Rendemen," Jom Fmipa, vol. 1, no. 2, pp. 48-54, 2014.

[11] SNI (1995), Arang Aktif Teknis, Standar Nasional Indonesia, No. 06-3730-1995, Departemen Perindustrian RI: hal 29 - 57.

[12] M. Faizal, I. Andynapratiwi, and P. D. A. Putri, "Pengaruh Komposisi Arang Dan Perekat Terhadap Kualitas Biobriket Dari Kayu Karet," J. Tek. Kim., vol. 20, no. 2, pp. 36-44, 2014.

[13] S. Hartanto and Ratnawati, "Pembuatan Karbon Aktif dari Tempurung Kelapa Sawit dengan Metode Aktivasi Kimia," J. Sains Mater. Indones., vol. 12, no. 1, pp. 12-16, 2010.

[14] Z. A. Nasution and S. M. Rambe, "Pengaruh temperatur terhadap pembentukan pori arang cangkang sawit sebagai adsorbansi effect of temperature for palm shell pore forming as adsorbance," Din. Penelit. Ind., vol. 22, no. 1, pp. 48-53, 2011.

[15] R. T. Yang, "Active carbon. By H. Jankowska, A. Swiatkowski, and J. Choma, Ellis Horwood, West Sussex, England, and Prentice-Hall, Englewood Cliffs, NJ, 1991, 280 pp," AIChE J., vol. 38, no. 12, pp. 1998-1998, 1992.

[16] PERMENKES, "Peraturan Menteri Kesehatan Republik Indonesia Nomor 492/Menkes/Per/IV/2010 tentang Persyaratan Kualitas Air Minum," Depkes, no. 492, p. 9, 2010.

[17] W. iqbal Mubarak and N. Chayatin, Ilmu kesehatan masyarakat: Teori dan Aplikasi, vol. 53, no. 9. 2009.

[18] S. Jamilatun and M. Setyawan, "Pembuatan Arang Aktif dari Tempurung Kelapa dan Aplikasinya untuk Penjernihan Asap Cair," SPEKTRUM Ind., vol. 12, no. 1, p. 73, 2014. 